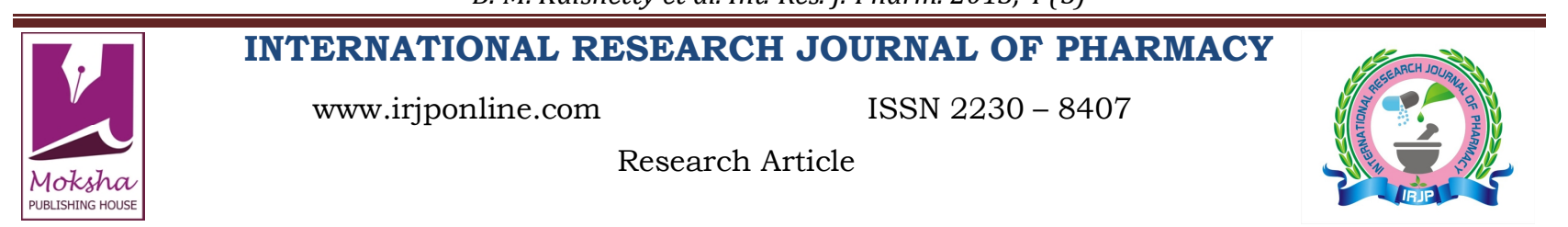

\title{
ASSESSMENT AND TOXICITY OF FLUORIDE FROM GROUND WATER SOURCES IN AND AROUND BAGALKOT DISTRICT, KARNATAKA, INDIA
}

\author{
B. M. Kalshetty ${ }^{1}$, S.M.Gaonkar ${ }^{2}$, R. S. Gani ${ }^{3}$, M.B.Kalashetti ${ }^{4}$ \\ ${ }^{1}$ B.H.S.Arts and T.G.P.Science College, Jamkhandi, Dist: Bagalkot, India \\ ${ }^{2}$ Department of Chemistry, Basaveshwar Science College, Bagalkot, India \\ ${ }^{3}$ Research Scholars, Department of Chemistry, Bharathier University, Coimbatore, India \\ ${ }^{4}$ P.G. Studies in Department of Chemistry, Karnataka University, Dharwad, India \\ *Corresponding Author Email: drkalshetty@gmail.com
}

Article Received on: 13/03/13 Revised on: 17/04/13 Approved for publication: 11/05/13

DOI: $10.7897 / 2230-8407.04552$

IRJP is an official publication of Moksha Publishing House. Website: www.mokshaph.com

(C) All rights reserved.

\section{ABSTRACT}

Physico-Chemical analysis of ground water samples was carried out from 20 locations of Bagalkot, Badami and Hungund and Ilkal taluks. The analysis of different parameters such as Temperature, pH, EC, TDS and Fluoride were carried out as per the standard methods. All the parameters studied were within the permissible limit except Fluoride content in few locations. The analyzed results indicate the Fluoride concentration in some sampling spots namely Simikeri (Govt. Primary School Campus) of Baglkot Taluk, Maradi village and Budanagad village of Badami Taluk, Yarigonal village, Ilkal (Near Municipalty) and Aminagad (Gudur Cross) of Hungund taluk were found above standards probably due to seasonal variations and salt water contamination. Fluoride ion in water sources is known for both beneficial and detrimental effects on live stock. The higher concentration of Fluoride in ground water causes a disease called "Fluorosis". It is a slow, progressive, crippling malady, which affects every organ, tissue and cells in the body and results in health complaints having overlapping manifestations with several other diseases like chronic dental and skeletal Fluorosis.

Keywords: Fluoride, Fluorosis, Ground water, Fluoride exposure and Toxicity.

\section{INTRODUCTION}

Fluoride occurs in combined state, it is present naturally in almost all foods and beverages including water, but levels of which can vary widely. Fluoride in drinking water to adjust concentrations in between $0.8 \mathrm{ppm}$ to $1.0 \mathrm{ppm}$ for the beneficial effect of teeth decay prevention. The Fluoride accumulation of ground water varies according to the source of water, area with semi-arid, climate, crystalline rock and alkaline soils of the area. The types of rocks composition of the host rock that water flows through and amount of rain fall $^{1}$ are mainly affected. Fluoride is a geochemical contaminant and natural sources account for most of the Fluoride in surface and ground water. Its concentration is dependent on solubility of Fluoride containing rocks.

Fluoride ion in drinking water is known for both beneficial and detrimental effects on health. WHO and Indian council of Medical Research described the drinking water quality guidelines values for Fluoride is $1.5 \mathrm{ppm}^{2,3}$. Low content ratio of Fluoride provides protection against dental caries, especially in children. In India around 60 million people including children were severely affected by Fluorosis because of high consumption of Fluoride content ${ }^{4}$. Longer exposure to Fluoride leads to certain types of bone diseases, mottling of teeth-enamel, nervous and skeletal disorder ${ }^{5}$. It also adversely affects the foetal cerebral function and neurotransmitters ${ }^{6}$.

The number of people getting affected, meanwhile villages, blocks, districts and states endemic for Fluorosis have been steadily increasing ever since the disease was discovered in India during 1930s. The reason for the increase in the disease incidence and the sizeable number of locations being identified as endemic zones for Fluorosis is due to overgrowth of population, necessitating more and more water, resorting to the use of hand pump water, unawareness regarding the importance of checking water quality especially for Fluoride content and due to water shortage. The agencies responsible for water supply (Municipal authorities) resort to pumping water from open wells bore wells to overhead tanks or direct supply to residents, and invariably such water sources are not tested for Fluoride ${ }^{7}$.

Keeping in view of the above and increased in recent trends in Fluoride concentration in natural waters and various adverse impacts on human health. An investigation should be under taken in and around Bagalkot district of Karnataka State. It is proposed to carry out a systematic study to estimate Fluoride contamination of ground water resources in Hunagund, Ilkal, Badami and certain areas of Bagalkot district. The present investigation is useful to perform remedial measures and to give awareness about Fluorosis to the public residing in the study areas.

\section{MATERIAL AND METHODS}

Water samples were collected from 20 sampling locations selected for analysis of their quality. 5 samples from Bagalkot taluks, 7 samples from Badami and 8 samples from Hunagund taluk of Bagalkot District. Bagalkot district comprises 6 taluks namely Jamkhandi, Mudhol, Bilagi, Bagalkot, Hunagund and Badami. For first instant we have selected 3 taluks for the assessment of water quality. Samples for assessment were collected in well sterilized bottles from 3 clusters using the standard methods. While collection of samples the water temperature recorded in between $24^{\circ} \mathrm{C}$ to $29.5^{\circ} \mathrm{C}$. The analysis of Physico-chemical parameters namely Temperature, $\mathrm{pH}, \mathrm{EC}$, TDS and Fluoride were analyzed as per the Standard methods ${ }^{8}$. Determination of Fluoride has been carried out using Fluoride ion selective electrode (Thermo Scientific Orion, Combination Fluoride Electrode No. 9609 BNWP) as described in standard procedure 9 .

All the chemicals and reagents such as Sodium fluoride, zirconyl chloride, 3-alizarin sulphuric acid sodium salts used were of analytical grade. Doubled distilled water was used for preparing of solutions. The Physico-chemical analysis 
B. M. Kalshetty et al. Int. Res. J. Pharm. 2013, 4 (5)

results and Fluoride concentration in the collected ground water samples as represented in Table 1 to Table 3 . These values were further compared with the drinking water standards (Table 4) of Bureau of Indian standards and World Health Organization for evaluation of Fluoride concentration in the study area.

Table 1: Physico-Chemical parameters and Fluoride content in ground water Location: Bagalkot Taluk, India

\begin{tabular}{|c|c|c|c|c|c|c|}
\hline Sampling spots & Location & Temp. & pH & EC & TDS & Fluoride \\
\hline Spot BK1 & Tulasigeri Near temple & $28.3^{\circ} \mathrm{C}$ & 6.7 & 1.510 & 790 & 1.50 \\
\hline Spot BK2 & Semikerin School Compus & $28.1^{\circ} \mathrm{C}$ & 6.6 & 1.683 & 786 & 2.23 \\
\hline Spot BK3 & Muchandi Village & $28.4^{\circ} \mathrm{C}$ & 6.8 & 1.360 & 634 & 0.47 \\
\hline Spot BK4 & Sirur Village & $28.7^{\circ} \mathrm{C}$ & 6.7 & 1.570 & 723 & 0.48 \\
\hline Spot BK5 & Mannikeri Village & $29.0^{\circ} \mathrm{C}$ & 6.9 & 1.710 & 634 & 0.72 \\
\hline
\end{tabular}

Table 2: Physico-Chemical parameters and Fluoride content in ground water Location: Badami Taluk, India

\begin{tabular}{|c|c|c|c|c|c|c|}
\hline Sampling spots & Location & Temp. & pH & EC & TDS & Fluoride \\
\hline Spot BD1 & Agasanakoppa Village & $28.0^{\circ} \mathrm{C}$ & 7.1 & 1.51 & 778 & 0.34 \\
\hline Spot BD2 & Kerur Town & $28.2^{\circ} \mathrm{C}$ & 7.0 & 1.95 & 821 & 0.53 \\
\hline Spot BD3 & Badami Rly. Station & $28.3^{\circ} \mathrm{C}$ & 6.7 & 1.96 & 839 & 0.14 \\
\hline Spot BD4 & Khyad -Village & $28.5^{\circ} \mathrm{C}$ & 6.7 & 1.82 & 820 & 0.53 \\
\hline Spot BD5 & Maradi-Village & $28.3^{\circ} \mathrm{C}$ & 7.6 & 1.46 & 925 & 1.80 \\
\hline Spot BD6 & Guledgudda-town & $28.4^{\circ} \mathrm{C}$ & 6.5 & 1.72 & 790 & 0.75 \\
\hline Spot BD7 & Budangad-village & $28.7^{\circ} \mathrm{C}$ & 7.5 & 1.61 & 900 & 2.80 \\
\hline
\end{tabular}

Table 3: Physico-Chemical parameters and Fluoride content in ground water. Location: Hungund Taluk, India

\begin{tabular}{|c|c|c|c|c|c|c|}
\hline Sampling spots & Location & Temp. & pH & EC & TDS & Fluoride \\
\hline Spot HND1 & Kalligudda-Village & 28.5 & 6.5 & 1.22 & 835 & 1.48 \\
\hline Spot HND2 & Aihole-Village & 29.2 & 6.6 & 1.13 & 891 & 0.59 \\
\hline Spot HND3 & Kelur-Village & 29.3 & 6.8 & 1.15 & 869 & 1.48 \\
\hline Spot HND4 & Hunagund-Town & 29.4 & 6.7 & 1.20 & 790 & 0.49 \\
\hline Spot HND5 & Yarigonal-Village & 29.4 & 7.2 & 1.25 & 742 & 5.39 \\
\hline Spot HND6 & Ilka-Town studio & 29.5 & 7.0 & 1.13 & 956 & 3.36 \\
\hline Spot HND7 & Ilkal-Town ward-4 & 29.1 & 7.1 & 1.42 & 872 & 1.41 \\
\hline Spot HND8 & Aminagad-Gudur Cross & 29.0 & 7.1 & 1.25 & 786 & 1.75 \\
\hline
\end{tabular}

Table 4: Water Quality Standards for Comparison of Results

\begin{tabular}{|c|c|c|c|c|}
\hline Parameters & Unit & WHO & ISI & BIS \\
\hline $\mathrm{pH}$ & --- & $6.5-8.5$ & $6.5-8.5$ & $7-8$ \\
\hline EC & $\mathrm{m}$ mhos/cm & 1.4 & 1.4 & 300 \\
\hline TDS & Ppm & $<500$ & $<500$ & $<500$ \\
\hline TA & Ppm & 120 & $75-120$ & 120 \\
\hline TH & Ppm & 500 & 500 & 300 \\
\hline DO & Ppm & $4-6$ & 7 & $4-6$ \\
\hline Fluoride & Ppm & $1-1.5$ & $1-1.5$ & $1-1.4$ \\
\hline Chloride & Ppm & 200 & 250 & 200 \\
\hline Sulphate & Ppm & 150 & $150-250$ & 150 \\
\hline Calcium & Ppm & 75 & $75-100$ & 75 \\
\hline Magnesium & $\mathrm{ppm}$ & 50 & $30-150$ & 50 \\
\hline
\end{tabular}

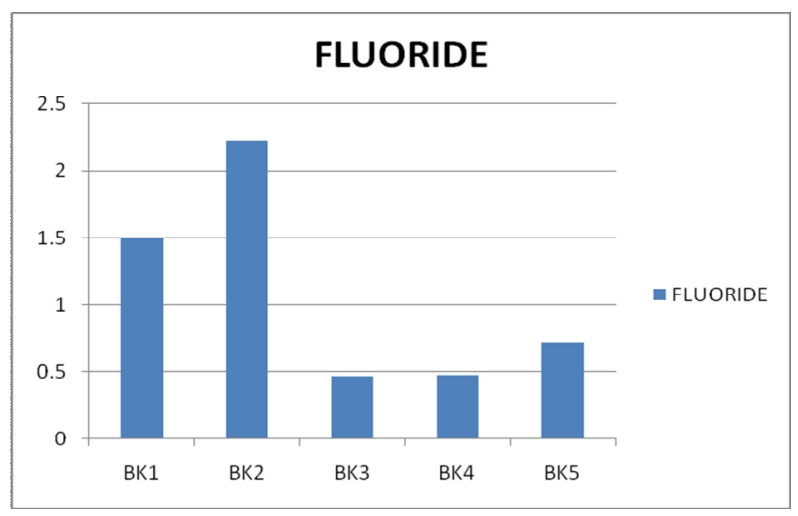

Figure 1: Fluoride contents in Bagalkot Locations

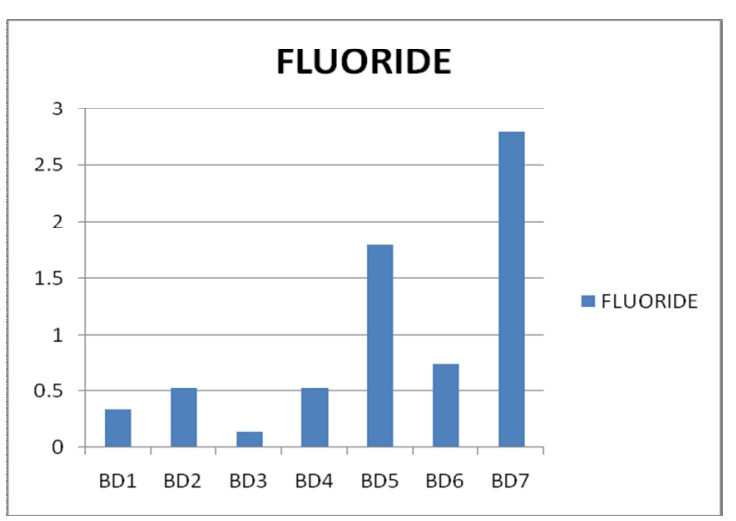

Figure 2: Fluoride contents in Badami Locations 


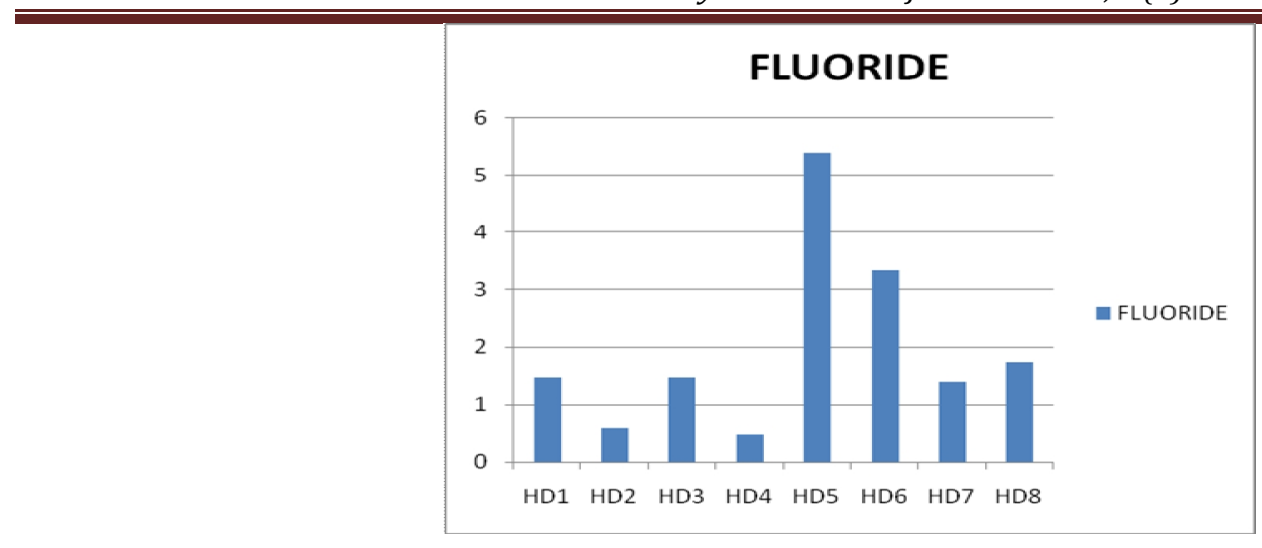

Figure 3: Fluoride contents in Hunagund Locations

\section{RESULTS}

The analysis results of ground water obtained, for the various parameters such as Temperature, pH, EC, TDS and Fluoride concentration in water samples of study area:

\section{DISCUSSION \\ Temperature}

Temperature of the water is an important parameter because it effects bio-chemical reactions in aquatic organisms. A rise in temperature of water leads to the speeding up of chemical reactions in water body, reduces the solubility of gases and amplifies the tastes and odours. The temperature of water samples in the present study ranged in between $24^{\circ} \mathrm{C}$ to $29.5^{\circ} \mathrm{C}$

\section{Power of Hydrogen (pH)}

$\mathrm{pH}$ is considered as an important ecological factor and it is a term used universally to express the intensity of the acid and alkaline condition of a solution or water. Most of the waters of ground water were slightly alkaline due to the presence of $\mathrm{CO}_{3} \cdots$ and $\mathrm{HCO}_{3}$. The $\mathrm{pH}$ values of ground water of sampling spots of Bagalkot locations found in between 6.6 to 6.9 all are found within the permissible limit. 6.5 to 7.6 and 6.5 to 7.1 were found in the sampling spots of Badami and Hunagund taluks respectively. All values were found in between prescribed ranges of International Standards. The $\mathrm{pH}$ value of about 6 samples out of 20 samples of ground water of the study area were more than 7.0 may reflect contamination of bases like Sodium hydroxide and Calcium hydroxide ${ }^{10}$.

\section{Electrical Conductivity (EC)}

It is a measure of water capacity to convey electric current. It signifies the amount of total dissolved solids. The presence of high EC values in water indicates the presence of high amount of dissolved inorganic substances in ionized form. $\mathrm{EC}$ is an indicator of degree of mineralization of water. The EC values always are correlated with TDS found in water. In the present investigation the EC values ranged in between $1.36 \mathrm{~m} \mathrm{mhos} / \mathrm{cm}$ to $1.71 \mathrm{~m} \mathrm{mhos} / \mathrm{cm}$ in Bagalkot locations except Muchandi-village, all the sampling spots of Bagalkot region Ec values found slightly more than the permissible limit $(1.4 \mathrm{~m} \mathrm{mhos} / \mathrm{cm})$ indicates the presence of Total Dissolved Solids in ground water samples.

The EC values of Badami and Hunagund sampling spots were found in between $1.51 \mathrm{~m} \mathrm{mhos} / \mathrm{cm}$ to $1.96 \mathrm{~m} \mathrm{mhos} / \mathrm{cm}$ and $1.15 \mathrm{~m} \mathrm{mhos} / \mathrm{cm}$ to $1.42 \mathrm{~m} \mathrm{mhos} / \mathrm{cm}$ respectively. The more EC values in Badami sampling spots may be due to content substantial amounts of dissolved $\mathrm{CO}_{2}, \mathrm{HCO}_{3}{ }^{-}$and hydroxides. These constituents are the results of dissolution of minerals in the soil and atmosphere ${ }^{11}$. The EC values of Hunagund sampling spots found within the legal limit.

\section{Total Dissolved Solids (TDS)}

TDS indicates the salinity behavior of ground water. Water containing more than $500 \mathrm{ppm}$ of TDS is not considered desirable for drinking water supplies, but in unavoidable cases $1500 \mathrm{ppm}$ is also allowed ${ }^{12}$. In the present investigation the TDS values of Bagalkot sampling spots ranged in between $634 \mathrm{ppm}$ to $790 \mathrm{ppm}$, Badami samplings ranged in between $778 \mathrm{ppm}$ to $925 \mathrm{ppm}$ and Hunagund area water samples values were found in between $786 \mathrm{ppm}$ to $956 \mathrm{ppm}$, all values were found more than the permissible legal limits.

\section{Fluoride Ion Concentration}

Fluoride is a geochemical contaminant and natural sources account for most of the Fluoride in surface and ground water. Its concentration is dependent on solubility of Fluoride bearing rocks such as Fluorspar, Cryolite, Fluorspatite and hydroxyl apatite etc., in the present investigation of water samples of 3 taluks out of 20 samplings 6 samples contain more Fluoride concentrations. Simikeri- Village (Govt. Primary School Campus) spot BK2 (2.23 ppm) of Bagalkot taluk, Maradi-village spot BD5 (1.8 ppm) and Budanagudvillage spot BD7 (2.88 ppm) of Badami taluk . three villages of Hungund taluk namely Yarigonal-village spot H5 (5.39 ppm), Ilkal (Near Municipality) spot HND6 (3.36 ppm) and Aminagad (Gudur cross) spot HND8 (1.75 ppm). Figure 1 to Figure 3 showed the Fluoride concentrations in different study areas of Bagalkot, Badami and Hunagund regions of Bagalkot District.

High values of Fluoride cause Fluorosis which is characterized by molting of teeth enamel, nervous and skeletal disorder. Chemical composition of ground water is affected by concurrence of several factors like climatic conditions; these show their positive influence on Fluoride distribution in the study area. Ground water with high Fluoride contents are generally Bicarbonate, Sodium mixed water, particularly poor in Calcium content. Rocks which are rich in Fluoride minerals contributed enriched Fluoride contents of ground water. The content of Fluoride is related to depth of the wells and water source. In these areas, there is no Industry or any human activity that can cause anthropogenic contamination of the ground water with Fluoride and in such area high levels of Fluoride are due to geogenic sources.

It has been observed that the study area showed variation in Fluoride concentration this may be presence of Fluoride 
bearing minerals in the host rocks and their interaction with ground water. Regular intake of Fluoride rich waters seems to be the main cause for Fluorosis in the study area. Thus, these results will be helpful to prepare Fluorosis mitigation plan for the affected population of the study area. Fluoride has widely been in the focus of public and scientific interest because of their important physiological role in the health of human being.

Now it is a proper time found to minimize the Fluoride concentration for maintaining the good health of the public residing at the study area. It is quite necessary to carry out an important studies on hydro-chemical and hydro-geological aspect of occurrence of Fluoride which can be useful to mitigate Fluorosis in those study areas. The defluoridation tanks should also be installed in such area which is having high concentration of Fluoride in ground water; the possibilities of bringing safe water from nearby villages can also be planned with village people and local authorities through community participation.

\section{CONCLUSION}

It is observed from the above study that Fluoride content in certain areas of Bagalkot, Badami, Hungund and Ilkal was found more than prescribed standard limits. Fluoride concentration can be diluted by inducing ground water recharge techniques, i.e., construction of percolation tanks, flooding of ground water by mixing surface water by promoting rain water harvesting.

\section{Suggestions}

1. Monitoring system is to be established to periodically evaluate the prevalence of Fluorosis and dental caries in the affected area.

2. A Registry of water Fluoride concentration may be kept in municipalities, for the benefit of Public Health Providers, health professionals and the public with regard to Fluoride consuming from drinking water.
ACKNOWLEDGEMENT

Authors express their sincere thanks to Dr. C.N.R.Rao, FRS National Research Professor, Chairman Vision Group on Science and Technology, Bangalore and Dr. Ananth Raj Executive Secretary VGST group, Bangalore for providing financial support in terms of Major Projects. The authors are also thankful to Dr. B.G.Mulinami Vice- Chancellor and chief Administrative Officer, S.H.Lagali and S.K.Biradar Administrative Officers BLDE'S Association Bijapur and Principal Dr. S.S.Suvarnakhandi for providing necessary facilities required to carry out this research work. We are very much thankful to Principal B.V.V.S. Polytecnic College Bagalkot for providing Instrumental facility required to carry out this research work.

\section{REFERENCES}

1. Meenakhi S, Maheswari RC. J.Hazard Mater., 2006;137:456. http://dx.doi.org/10.1016/j.jhazmat.2006.02.024

2. Guidelines for drinking water quality: International Standards for Drinking water, world health organization, $1963 ; 2^{\text {nd }}$ edition.

3. Manual of Standards of Quality for Drinking Water Supplies, special report series, Indian Council of Medical Research, 1975; $2^{\text {nd }}$ ed., Vol. 44.

4. Bendale DS, Choudhari GR, Gupta GK. An Evaluation of ground water quality, 2010.

5. Sushhela AK, Treatic of fluorosis, Fluorosis Research in Rural Development Foundation, Delhi, 2001.

6. Yu Y, Yang W, Dong Z. Fluoride Research Report, 2000;33.

7. Treatise on fluorosis, Fluorosis Research and Rural Development Foundation, Delhi $20073^{\text {rd }}$ Revised Edition.

8. APHA, Standard methods for the examination of water and waste water, $1995 ; 19^{\text {th }}$ edition, Washington, D.C.

9. Standard methods for the examination of water and waste water, American Public Health Association (APHA) / American water works Association / Water Environment Federation, Washington, D.C., USA, $1998 ; 2^{\text {nd }}$ ed.

10. Languir D, Aqueous Environmental Chemistry, Prentise-Hall, Inc. New Jersey, 1997.

11. Nagaraju A, Suresh S, Killham K, Hudson K. Edward, Turkish J. Eng. Env. Sci., 2006; 30,203.

12. Shrinivasa Rao B. ,Venkateshwaralu P. Indian J. Environ. Prot., 2000 ; 20(3), 1617

Cite this article as:

B. M. Kalshetty, S.M.Gaonkar, R. S. Gani, M.B.Kalashetti. Assessment and toxicity of fluoride from ground water sources in and around Bagalkot district, Karnataka, India. Int. Res. J. Pharm. 2013; 4(5):246-249 